\title{
Phosphorus release of metazoan zooplankton in two bays with different trophic status in Lake Taihu (China)
}

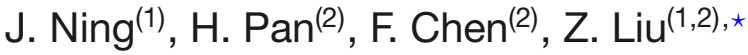 \\ Received December 9, 2012 \\ Revised April 7, 2013 \\ Accepted April 10, 2013
}

\section{ABSTRACT}

Key-words:

Lake Taihu, subtropical lake, metazoan zooplankton, phosphorus release
The contribution of metazoan zooplankton to internal phosphorus $(\mathrm{P})$ cycling was investigated in Meiliang and Wuli Bays of Lake Taihu, a eutrophic, shallow lake in China by determining biomass and biomass specific $P$ release rates. The zooplankton community of eutrophic Meiliang Bay was dominated by cladocerans, particularly Daphnia spp. and copepods, while dominant groups in hypereutrophic Wuli Bay included rotifers, copepods, and cladocerans. Release rates of $\mathrm{PO}_{4}^{3-}-\mathrm{P}$ ranged from 0.20 to $0.57 \mathrm{mg} \cdot \mathrm{g}$ (dry weight) ${ }^{-1} \cdot \mathrm{h}^{-1}$ in Meiliang Bay and 0.20 to $0.76 \mathrm{mg} \cdot \mathrm{g}^{-1} \cdot \mathrm{h}^{-1}$ in Wuli Bay. In most cases, $P$ release rates were higher in Wuli Bay than Meiliang Bay. Phosphorus fluxes from zooplankton excretion varied from 5.34 to $57.41 \mathrm{mg} \cdot \mathrm{m}^{-2} \cdot \mathrm{d}^{-1}$ in Meiliang Bay and 8.20 to $70.02 \mathrm{mg} \cdot \mathrm{m}^{-2} \cdot \mathrm{d}^{-1}$ in Wuli Bay. Since P released by zooplankton in this study was in a form available to phytoplankton, zooplankton may represent a significant source of $\mathrm{P}$ contributing to high phytoplankton biomass in Lake Taihu.

\section{RÉSUMÉ}

Rejet de phosphore par le zooplancton métazoaire dans deux baies d'état trophique différent du lac Taihu (Chine)

Mots-clés:
lac Taihu,
lac subtropical,
zooplancton
métazoaire,
rejet
de phosphore

La contribution du zooplancton métazoaire à la circulation du phosphore interne $(P)$ a été étudiée dans les baies Meiliang et Wuli du lac Taihu, un lac eutrophe, peu profond en Chine, par la détermination de la biomasse et les taux de libération de $\mathrm{P}$ par biomasse spécifique. La communauté du zooplancton de la baie eutrophe Meiliang a été dominée par les cladocères Daphnia spp, en particulier, et des copépodes, tandis que les groupes dominants dans la baie hypereutrophe Wuli comprenaient des rotifères, des copépodes, et des cladocères. Les taux de libération de $\mathrm{PO}_{4}^{3-}-\mathrm{P}$ variaient de 0,20 à $0,57 \mathrm{mg} \cdot \mathrm{g}$ (poids sec) ${ }^{-1} \cdot \mathrm{h}^{-1}$ dans la baie Meiliang et de 0,20 à $0,76 \mathrm{mg} \cdot \mathrm{g}^{-1} \cdot \mathrm{h}^{-1}$ dans la baie Wuli. Dans la plupart des cas, les taux de rejet en $\mathrm{P}$ étaient plus élevés dans la baie de Wuli que dans la baie Meiliang. Les flux de phosphore provenant de l'excrétion du zooplancton varient de 5,34 à $57,41 \mathrm{mg} \cdot \mathrm{m}^{-2} \cdot \mathrm{d}^{-1}$ dans la baie Meiliang et de $8,20 \mathrm{à} 70,02 \mathrm{mg} \cdot \mathrm{m}^{-2} \cdot \mathrm{d}^{-1}$ dans la baie Wuli. Comme le P libéré par le zooplancton dans cette étude était dans une forme disponible pour le phytoplancton, le zooplancton peut représenter une source importante de $\mathrm{P}$ contribuant à la biomasse phytoplanctonique élevée dans le lac Taihu.

(1) Department of Ecology and Institute of Hydrobiology, Jinan University, Guangzhou 510632, P.R. China 


\section{INTRODUCTION}

Phosphorus $(P)$ is often a key factor controlling eutrophication in lacustrine systems. Major $P$ sources typically include urban and agricultural runoffs and internal fluxes. In shallow, eutrophic lakes, $P$ flux from the sediment is an important internal process maintaining a high water column P pool (Søndergaard et al., 2012). Excretion by zooplankton also is considered an internal source of P (Lehman, 1980b; Urabe et al., 1995; Kowalczewska-Madura and Gołdyn, 2010). Grazing by large zooplankton, particularly cladocerans, can regulate phytoplankton biomass and species composition (Carpenter et al., 1987; Reynolds, 1994; Sommer and Sommer, 2006). However, nutrient excretion by zooplankton may also affect the supply and stoichiometry of nutrients and thereby influence phytoplankton and lake trophic status (Lehman, 1980a; Elser et al., 1988; Sterner and Hessen, 1994; Kowalczewska-Madura et al., 2007).

The role of zooplankton has been well studied in temperate lakes, but and less so in tropical and subtopical systems where zooplankton are smaller and likely to be less efficient in grazing phytoplankton (Jeppesen et al., 2010; Havens and Beaver, 2011). However, small zooplankton exhibit high $\mathrm{P}$ release rates and may thus play a significant role in nutrient cycling in tropical and subtropical lakes (Pinto-Coelho and Greco, 1999). Lake Taihu is a subtropical freshwater lake in China's Yangtze delta, with a surface area of $2338 \mathrm{~km}^{2}$ and mean depth of $1.89 \mathrm{~m}$. Situated in one of the most rapidly industrializing and populous regions of the world, Lake Taihu has suffered greatly from anthropogenic eutrophication since the 1980s (Qin et al., 2007). Although the lake is well-mixed and usually turbid due to sediment resuspension and high phytoplankton biomass, a clear water phase may be observed in spring and early summer due to low phytoplankton abundance. Water transparency decreases later in summer due to Microcystis blooms, while large zooplankton, particularly Daphnia spp., decrease in density, most likely due to increased fish predation and reduced food quality (Yang et al., 2008; Song et al., 2010; De Kluijver et al., 2012). In this study, the role of zooplankton in nutrient cycling in Lake Taihu was evaluated through estimates of $P$ release and flux by metazoan zooplankton were estimated compared with data on $P$ release from sediments and external $\mathrm{P}$ loading gleaned from the literature. The work contributes to a better understanding of the role of zooplankton in subtropical lakes.

\section{STUDY SITE}

Two areas with contrasting trophic states (Song et al., 2010) located in the north part of Lake Taihu (Figure 1) were selected for this study. Meiliang Bay (area $124 \mathrm{~km}^{2}$, average depth $2.1 \mathrm{~m}$ ) exhibits total nitrogen levels ranging from 2.3 to $5.2 \mathrm{mg} \cdot \mathrm{L}^{-1}$ and total phosphorus ranging from 0.12 to $0.31 \mathrm{mg} \cdot \mathrm{L}^{-1}$, and experiences severe summer algal blooms dominated by cyanobacteria. Wuli Bay (area $9 \mathrm{~km}^{2}$, average depth $1.8 \mathrm{~m}$ ), considered the most polluted area of main Lake Taihu, is isolated artificially from Meiliang Bay by a dam. Total nitrogen here ranges from 3.13 to $8.85 \mathrm{mg} \cdot \mathrm{L}^{-1}$ and total phosphorus from 0.15 to $0.24 \mathrm{mg} \cdot \mathrm{L}^{-1}$ (Table I).

\section{MATERIALS AND METHODS}

Vertical integrated water samples from the surface to a depth of about $1.5 \mathrm{~m}$ were taken with a tube sampler biweekly in March-May 2004 in Meiliang Bay and Wuli Bay (Figure 1). For identification and enumeration of zooplankton, samples were filtered with a $63-\mu \mathrm{m}$ sieve into plastic vials and preserved with $5 \%$ formalin solution. Zooplankton were identified according to Wang (1961), Zhuge (1997), Shen (1979) and Chiang \& Du (1979). Animals were counted, and the lengths of 20-30 individuals were measured using a microscope. Zooplankton biomass (Bz), expressed as $\mathrm{mg}$ (dry weight). $\mathrm{L}^{-1}$ or $\mathrm{g} \cdot \mathrm{m}^{-3}$, was estimated according to length-weight relationships given in the literature (Dumont et al., 1975; Huang and Hu, 1986). 


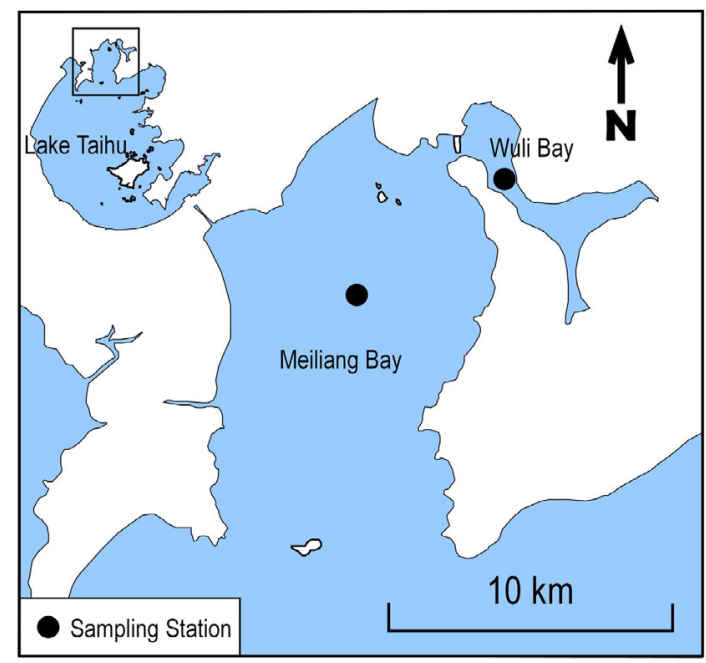

\section{Figure 1}

Sampling stations in Meiliang Bay and Wuli Bay, Lake Taihu.

\section{Table I}

Mean and range of environmental variables in Meiliang Bay and Wuli Bay.

\begin{tabular}{|l|c|c|c|c|}
\hline \multirow{2}{*}{ Parameters } & \multicolumn{2}{|c|}{ Meiliang Bay } & \multicolumn{2}{c|}{ Wull Lake } \\
\cline { 2 - 5 } & Mean & Range & Mean & Range \\
\hline Water Depth $(\mathbf{m})$ & 2.1 & & 1.8 & \\
\hline Secchi Depth $(\mathbf{c m})$ & 25 & $15-32$ & 38 & $27-49$ \\
\hline Total nitrogen $\left(\mathbf{m g} \cdot \mathbf{L}^{-1}\right)$ & 3.34 & $2.32-5.20$ & 5.25 & $3.13-8.85$ \\
\hline Total phosphorus $\mathbf{( m g \cdot \mathbf { L } ^ { - 1 } )}$ & 0.19 & $0.12-0.31$ & 0.20 & $0.15-0.24$ \\
\hline Chlorophyll a $\mathbf{( m g} \cdot \mathbf{m}^{-3}$ ) & 32.91 & $9.20-65.88$ & 54.30 & $38.25-73.85$ \\
\hline
\end{tabular}

\section{Table II}

Incubation temperatures for zooplankton $P$ release experiments.

\begin{tabular}{|l|c|c|c|c|c|c|c|c|}
\hline Date & 9 Mar & 18 Mar & 26 Mar & 6 Apr & 15 Apr & 22 Apr & 16 May & 25 May \\
\hline Temperature $\left({ }^{\circ} \mathbf{C}\right)$ & 12.0 & 11.0 & 11.8 & 17.0 & 15.8 & 25.0 & 20.5 & 24.0 \\
\hline
\end{tabular}

On each experiment day, zooplankton were collected from each bay with horizontal hauls using a 63- $\mu \mathrm{m}$ mesh net. Although a plankton net of such mesh size could result in loss of smaller sized rotifers, a smaller sized net was not practical since it is difficult to separate animals from algae. After collection from the lake, zooplankton were transferred immediately into a $20-L$ tank containing filtered lake water, which was transported to the laboratory where zooplankton were concentrated with a $63-\mu \mathrm{m}$ sieve. After rinsing three times with distilled water, animals were transferred into three experimental flasks containing $500 \mathrm{ml}$ filtered $(0.45-\mu \mathrm{m})$ lake water. Temperature was maintained at or near in situ lake temperature (Table II). Three reference flasks without animals were run during each experimental series as controls. After incubation ( $1 \mathrm{~h}$ ), a $200-\mathrm{ml}$ water sample was taken by a pipette with the tip opening covered with a fine-mesh net to prevent the introduction of particles, such as feces. Water samples were analyzed for $\mathrm{PO}_{4}^{3-}-\mathrm{P}$ according to Murphy and Riley (1962). All experiments were carried out between $10 \mathrm{~h}$ and $15 \mathrm{~h}$.

At the end of the experiments, animals in each flask were filtered onto GF/C filters and dried at $60{ }^{\circ} \mathrm{C}$ for $24 \mathrm{~h}$. Dry biomass was determined using a microbalance. Phosphorus $\left(\mathrm{PO}_{4}^{3-}-\mathrm{P}\right)$ release rates were calculated as the difference between experimental and control flasks. Biomass specific $P$ release rate $(R p)$ was expressed per gram dry biomass per hour $\left(\mathrm{mg} \cdot \mathrm{g}^{-1} \cdot \mathrm{h}^{-1}\right)$. Daily zooplankton community $\mathrm{P}$ flux $(\mathrm{Pfz})$ was estimated by following formula:

$$
\mathrm{Pfz}=\mathrm{Rp} \times \mathrm{ZB} \times 24
$$




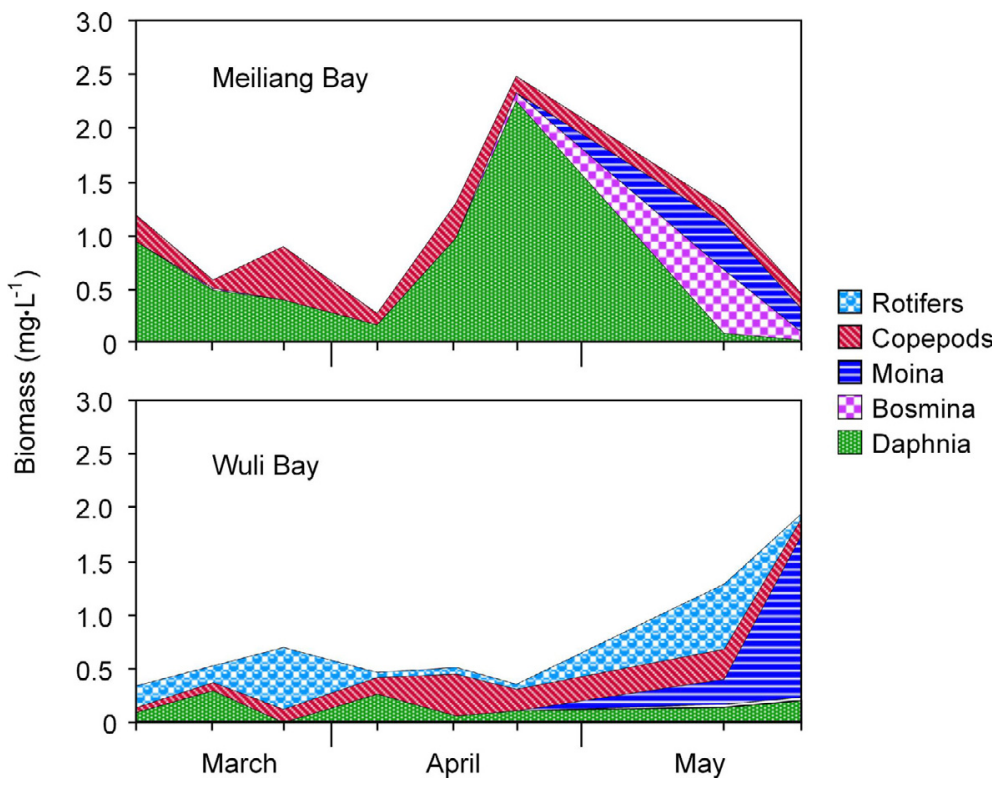

Figure 2

Biomass (dry weight) composition of metazoan zooplankton of Meiliang Bay and Wuli Bay, Lake Taihu during the study period.

Where Pfz is daily zooplankton community $\mathrm{P}$ flux, $\mathrm{mg} \cdot \mathrm{m}^{-2} \cdot \mathrm{d}^{-1} ; \mathrm{Rp}$ is biomass specific $\mathrm{P}$ release rate, $\mathrm{mg} \cdot \mathrm{g}^{-1} \cdot \mathrm{h}^{-1}$; ZB is zooplankton biomass expressed as $\mathrm{g} \cdot \mathrm{m}^{-2}$. $\mathrm{ZB}=\mathrm{Zb} \times \mathrm{D}$, where $\mathrm{Zb}$ is zooplankton biomass $\left(\mathrm{g} \cdot \mathrm{m}^{-3}\right)$, and $\mathrm{D}$ is the mean depth of the study area $(\mathrm{m})$.

$P$ release rates and fluxes of zooplankton in the two study bays were compared with a t-test using software SPSS 18.

\section{RESULTS}

Metazoan zooplankton community composition during the study period was similar in the two bays, but there were differences in dominant species. In Meiliang Bay, the dominant species included cladocerans Daphnia hyalina, D. longispina, D. pulex, Moina spp., Bosmina spp. and copepods Sinocalanus dorrii, Cyclops vicinus vicinus, C. strenuus, and Thermocyclops taihokuensis. However, in Wuli Bay, the dominant zooplankton species were rotifers Brachionus calyciflorus, B. angularis, Asplanchna priodonta, Keratella tropica, Polyarthra spp., Filinia longiseta, copepods Cyclops vicinus vicinus, Cyclops strenuus, Thermocyclops taihokuensis, Mesocyclops thermocyclopoides and cladocerans Moina spp.

Biomass (dry weight) of metazoan zooplankton in Meiliang Bay was variable (Figure 2). Cladocerans, dominated by Daphnia spp. from March to April and Bosmina spp. and Moina spp. in late May, were the largest component of zooplankton biomass, followed by copepods, while the biomass of rotifers was negligible.

In Wuli Bay, however, rotifers contributed a significant proportion of metazoan zooplankton biomass. Although cladocerans also were an important contributor to zooplankton biomass, the proportion was lower than in Meiliang Bay, and copepod biomass was similar in the two bays.

Mean $P$ release rates ranged from 0.20 to $0.57 \mathrm{mg} \cdot \mathrm{g}^{-1} \cdot \mathrm{h}^{-1}$ in Meiliang Bay and 0.20 to $0.76 \mathrm{mg} \cdot \mathrm{g}^{-1} \cdot \mathrm{h}^{-1}$ in Wuli Bay (Figure 3). In most cases, $\mathrm{P}$ release rates were higher in Wuli Bay than Meiliang Bay although only four experiments yielded statistically significant results. Based on biomass and release rates, zooplankton contribution to internal P cycling was estimated (Figure 4). Phosphorus flux varied from 5.34 to $57.41 \mathrm{mg} \cdot \mathrm{m}^{-2} \cdot \mathrm{d}^{-1}$ in Meiliang Bay and 8.20 to $70.02 \mathrm{mg} \cdot \mathrm{m}^{-2} \cdot \mathrm{d}^{-1}$ in Wuli Bay. Maximal values for $\mathrm{P}$ flux occurred at highest zooplankton biomasses. 


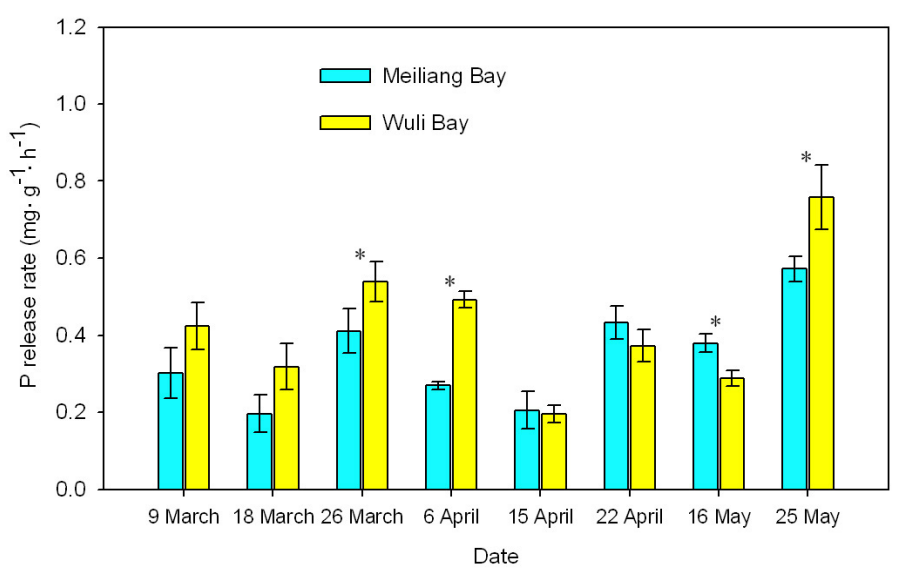

Figure 3

Phosphorous release rates of zooplankton in Meiliang Bay and Wuli Bay, Lake Taihu during the study period. Vertical bar shows standard deviation. ${ }^{*}$ Indicates that the difference is significant $(P<0.05)$.

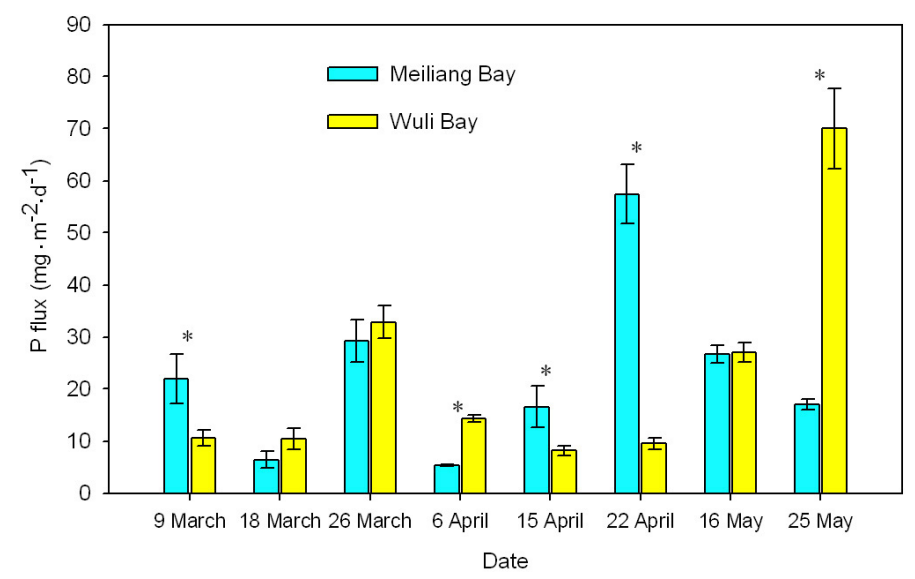

\section{Figure 4}

Phosphorus flux by metazoan zooplankton in Meiliang Bay and Wuli Bay, Lake Taihu during the study period. Vertical bar shows standard deviation. ${ }^{*}$ Indicates that the difference is significant $(P<0.05)$.

\section{DISCUSSION}

Zooplankton are an important influence on phytoplankton succession during spring and summer via grazing activity (Sommer et al., 1986). However, nutrient regeneration by zooplankton also is an important factor determining phytoplankton composition (Kowalczewska-Madura et al., 2007). Earlier studies revealed that most soluble $\mathrm{P}$ is released by zooplankton as $\mathrm{PO}_{4}^{-3}-$ $\mathrm{P}$ and, therefore, is available for phytoplankton growth (Lehman, 1980a). During our study, large zooplankton were abundant in Lake Taihu. The highest biomass of Daphnia spp. was more than $2.0 \mathrm{mg} \cdot \mathrm{L}^{-1}$. Zooplankton $\mathrm{P}$ release rates were variable but fall within ranges reported in other studies (Table III). In an experimental study, Lehman (1980b) reported a range of $0.58-0.83 \mathrm{mg} \cdot \mathrm{g}^{-1} \cdot \mathrm{h}^{-1}$ for zooplankton $\mathrm{P}$ release rates. Urabe et al. (1995) showed that zooplankton $\mathrm{P}$ release rates in Lake Biwa ranged from 0.01 to $0.11 \mathrm{mg} \cdot \mathrm{g}^{-1} \cdot \mathrm{h}^{-1}$. In a tropical reservoir, Pinto-Coelho and Greco (1999) reported zooplankton P excretion rates from 0.49 to $1.05 \mathrm{mg} \cdot \mathrm{g}^{-1} \cdot \mathrm{h}^{-1}$.

Our results showed differences in $\mathrm{P}$ release rates between the two bays with different eutrophication levels. In most cases, $\mathrm{P}$ release rates were higher in Wuli than Meiliang Bay, which may be attributed to differences in zooplankton community structure. Wuli Bay is close to the urban area of Wuxi and receives (treated and untreated) sewage. There were more rotifers in Wuli than in Meiliang Bay, while the number of large zooplankton, mainly Daphnia 
Table III

Literature comparison of $P$ release rates by zooplankton.

\begin{tabular}{|l|c|c|}
\hline Zooplankton & P release rate $\left(\mathrm{mg}^{\left.-\mathrm{g}^{-1} \cdot \mathrm{h}^{-1}\right)}\right.$ & References \\
\hline Zooplankton community & $0.20-0.76$ & Our study \\
\hline Zooplankton community & $0.49-1.05$ & Pinto-Coelho and Greco, 1999 \\
\hline Daphnia pulex & $0.58-0.83$ & Lehman, $1980 \mathrm{~b}$ \\
\hline Daphnia magna & $0.31-2.12$ & Ruan, 1999 \\
\hline Zooplankton community & $0.07-0.13$ & Gulati et al., 1995 \\
\hline Zooplankton community & $0.01-0.11$ & Urabe et al., 1995 \\
\hline
\end{tabular}

Table IV

Comparison of P fluxes from different sources of Lake Taihu.

\begin{tabular}{|l|c|c|}
\hline Sources & P fluxes $\left(\mathrm{mg}^{\left.-\mathrm{m}^{-2} \cdot \mathrm{d}^{-1}\right)}\right.$ & References \\
\hline Zooplankton P release $\left(\mathbf{P O}_{\mathbf{4}}-\mathbf{P}\right)$ & $5.3-70.0$ & Our study \\
\hline Sediment P release (PO $\left.\mathbf{P O}_{\mathbf{4}}-\mathbf{P}\right)$ & 3.0 & Fan and Wang, 2007 \\
\hline External P loading (TP) & 10.0 & Qin et al., 2007 \\
\hline
\end{tabular}

spp., in Meiliang Bay was higher than in Wuli Bay. Nutrient release rates are related inversely to zooplankton size (Pérz-Martínez and Gulati, 1999; Ruan, 1999). Given equal biomass, small zooplankton, such as rotifers, should play a more important role in $\mathrm{P}$ cycling than large-sized zooplankton, such as daphnids (Ejsmont-Karabin, 1983; Ejsmont-Karabin et al., 2004). Variation in zooplankton community composition likely is a main factor in the different $P$ release rates between Meiliang and Wuli Bay.

The contribution of zooplankton to internal P cycling was estimated by multiplying biomass specific excretion rates by integrated biomass on each sampling date. The lowest estimate was $5.34 \mathrm{mg} \cdot \mathrm{m}^{-2} \cdot \mathrm{d}^{-1}$ in Meiliang Bay when zooplankton biomass was lowest, while the highest value of $70.02 \mathrm{mg} \cdot \mathrm{m}^{-2} \cdot \mathrm{d}^{-1}$ was observed when both zooplankton biomass and $\mathrm{P}$ release rate were high in Wuli Bay. A recent study showed that mean $\mathrm{PO}_{4}^{3-}-\mathrm{P}$ release from Meiliang Bay sediments was below $3.0 \mathrm{mg} \cdot \mathrm{m}^{-2} \cdot \mathrm{d}^{-1}$ (Fan and Wang, 2007). The external loading of total $\mathrm{P}$ to Lake Taihu was $\sim 10.0 \mathrm{mg} \cdot \mathrm{m}^{-2} \cdot \mathrm{d}^{-1}$ (Qin et al., 2007), which is the same order of magnitude as $\mathrm{PO}_{4}^{3-}-\mathrm{P}$ flux from zooplankton excretion (Table IV). Considering that $\mathrm{P}$ released by zooplankton in this study was in a form available to phytoplankton, zooplankton may supply a significant source of $\mathrm{P}$ contributing to high phytoplankton biomass in Lake Taihu.

\section{ACKNOWLEDGEMENTS}

The study was supported by the National Basic Research Program of China (No: 2012CB956100) and National Natural Science Foundation of China (No: 41073057). The authors are grateful to Guijun Yang, Peisheng Huang, Xiaolan Song and Shouxuan Wu for their assistance in sampling and chemical analyses, and Mark McCarthy for English correction and valuable suggestions.

\section{REFERENCES}

Carpenter R., Kitchell J.F., Hodgson J.R., Cochran P.A., Elser J.J., Elser M.M., Lodge D.M., Kretchmer D., He X. and von Ende C.N., 1987. Regulation of lake primary productivity by food web structure. Ecology, 68, 1863-1876.

Chiang S.C. and Du N.S., 1979. Fauna Sinica, Crustacea, Freshwater Cladocera, Science Press, Beijing (in Chinese).

Dumont H.J., Van de Velde I. and Dumont S., 1975. The dry weight estimate of biomass in a selection of Cladocera, Copepoda and Rotifer from the plankton, periphyton and benthos of continental waters. Oecologia, 19, 75-97.

Ejsmont-Karabin J., 1983. Ammonia nitrogen and inorganic phosphorus excretion by the planktonic rotifers. Hydrobiologia, 104, 231-236. 
Ejsmont-Karabin J., Gorelysheva Z., Kalinowska K. and Weglenska T., 2004. Role of Zooplankton (Ciliata, Rotifera and Crustacea) in phosphorus removal from cycling: lakes of the river Jorka watershed (Masuria Lakeland, Poland). Pol. J. Ecol., 52, 275-284.

Elser J.J., Elser M.M., MacKay N.A. and Carpenter S.R., 1988. Zooplankton mediated transitions between N- and P-limited algal growth. Limnol. Oceanogr., 36, 64-90.

Fan C. and Wang C., 2007. Environmental geochemistry and eutrophication of the lake in the middle and lower reaches of the Yangtze River, Science Press, Beijing (in Chinese).

Gulati R. D., Martinez C. P. and Siewertsen K., 1995. Zooplankton as a compound mineralising and synthesizing system: phosphorus excretion. Hydrobiologia, 315, 1, 25-37.

Havens K.E. and Beaver J.B., 2011. Composition, size, and biomass of zooplankton in large productive Florida lakes. Hydrobiologia, 668, 49-60.

Huang X.F. and Hu C.Y., 1986. Regression equations of the body weight to body length for common freshwater species of cladoceran. In: Transactions of the Chinese Crustacean Society, No. I, Science Press, Beijing, 147-157 (in Chinese).

Jeppesen E., Meerhoff M., Holmgren K., González-Bergonzoni I., Mello F.T., Declerck S.A.J., De Meester L., Søndergaard M., Lauridsen T.L., Bjerring R., Conde-Porcuna J.M., Mazzeo N., Iglesias C., Reizenstein M., Malmquist H.J., Liu Z.W., Balayla D. and Lazzaro X., 2010. Impacts of climate warming on lake fish community structure and potential effects on ecosystem function. Hydrobiologia, 646, 73-90.

De Kluijver A., Yu J., Houtekamer M., Middelburg J. J. and Liu Z., 2012. Cyanobacteria as a carbon source for zooplankton in eutrophic Lake Taihu, China, measured by ${ }^{13} \mathrm{C}$ labeling and fatty acid biomarkers. Limnol. Oceanogr., 57, 4, 1245-1254.

Kowalczewska-Madura K. and Gołdyn R., 2010. Models of phosphorus turn-over in a hypertrophic lake: the Lake Swarzêdzkie case study. Oceanol. Hydrobiol. St., 39, 21-33.

Kowalczewska-Madura K., Gołdyn R. and Szyper H., 2007. Zooplankton phosphorus excretion in Swarzêdzkie Lake (Western Poland) and its influence on phytoplankton. Oceanol. Hydrobiol. St, 36, 3-16.

Lehman J.T., 1980a. Nutrient recycling as an interface between algae and grazers in freshwater communities. In: Kerfoot W.C. (ed.), Evolution and Ecology of Zooplankton Communities, The University Press of New England, Dartmouth, 251-263.

Lehman J.T., 1980b. Release and cycling of nutrients between planktonic algae and herbivores. Limnol. Oceanogr., 25, 620-632.

Murphy J. and Riley J.P., 1962. A modified single solution method for the determination of phosphate in natural water. Anal. Chim. Acta, 27, 31-36.

Pérz-Martínez C. and Gulati R.D., 1999. Species-specific N and $\mathrm{P}$ release rates in Daphnia. Hydrobiologia, 391, 147-155.

Pinto-Coelho R.M. and Greco M.K.B., 1999. The contribution of water hyacinth and zooplankton to the internal cycling of phosphorus in the eutrophic Pampulha Reservoir, Brazil. Hydrobiologia, 411, 115-127.

Qin B., Xu P., Wu Q., Luo L. and Zhang Y., 2007. Environmental issues of Lake Taihu, China. Hydrobiologia, 581, 3-14.

Reynolds C.S., 1994. The ecological basis for the successful biomanipulation of aquatic communities. Arch. Hydrobiol., 130, 1-33.

Ruan J.R., 1999. Estimation of orthophosphate release rate of zooplankton in freshwater microcosms. Acta Hydrobiol. Sin., 23, 204-209 (in Chinese with an English abstract).

Shen J.R., 1979. Fauna Sinica, Crustacea, Freshwater Copepoda, Science Press, Beijing (in Chinese).

Sommer U. and Sommer F., 2006. Cladocerans versus copepods: the cause of contrasting top-down controls on freshwater and marine phytoplankton. Oecologia, 147, 183-194.

Sommer U., Gliwicz Z.M., Lampert W. and Duncan A., 1986. The PEG-model of seasonal succession of planktonic events in fresh waters. Arch. Hydrobiol., 106, 433-471.

Song X., Liu Z., Yang G. and Chen Y., 2010. Effects of resuspension and eutrophication level on summer phytoplankton dynamics in two hypertrophic areas of Lake Taihu, China. Aquat. Ecol., 44, 41-54.

Søndergaard M., Bjerring R., and Jeppesen E., 2012. Persistent internal phosphorus loading during summer in shallow eutrophic lakes. Hydrobiogia, DOI 10.1007/s10750-012-1091-3. 
Sterner R.W. and Hessen D.O., 1994. Algal nutrient limitation and the nutrition of aquatic herbivores. Annu. Rev. Ecol. Syst., 25, 1-29.

Urabe J., Nakanishi M. and Kawabata K., 1995. Contribution of metazoan plankton to the cycling of nitrogen and phosphorus in Lake Biwa. Limnol. Oceanogr., 40, 232-241.

Wang J.J., 1961. Fauna Sinica, Rotifera, Science Press, Beijing (in Chinese).

Yang G., Pan H., and Liu Z., 2008. A comparative study on seasonal variations of crustaceans in the different lake areas in Lake Taihu. China Environ. Sci., 28, 27-32 (in Chinese with English abstract).

Zhuge Y., 1997. Studies on taxonomy and distribution of Rotifera in typical zones of China. Doctoral dissertation, Institute of Hydrobiology, Chinese Academy of Sciences (in Chinese with an English abstract). 